\title{
The Failure of the European Union to Respond to the Refugee Crisis
}

\author{
Abdullah Omar Yassen ${ }^{a}$, and Salam Abdullah Hassan ${ }^{b}$ \\ A \\ Department of Media Techniques, Erbil Technical Administrative College, Erbil \\ Polytechnic University, Kurdistan region of Iraq \\ B Near East University, Turkey
}

Article History: Received: 11 January 2021; Accepted: 27 February 2021; Published online: 5 April 2021

\begin{abstract}
Purpose: Recent UNHCR figures show that a record 70.8 million refugees are forcibly displaced. Millions of refugees are trapped in protracted refugee situations, and have been so on average for 25 years; this compares with 17 years in 2003, and nine in 1991. The research addresses whether the existing international refugee law regime is capable of addressing this crisis, or whether the issue is that member states do not comply with the refugee regime

Results: This research highlights the failure of European Union to respond to the refugee problems. The figures show that there are more refugees trapped in protracted situations than before and also that their plight takes longer to be resolved. Therefore, from the perspective of persons born in danger zones, one is more likely to be a refugee in 2019 than in 2014, yet less likely to find a durable solution.

Methodology: The study adopted a doctrinal methodology by exploring legislation and directives to identify whether these laws can address refugee issues.

Novelty/originality of this study: Forced migration has received negative media coverage and politicians, especially right-wing parties, have used migrants as a scapegoat. This paper identifies some of the myths of migration to demonstrate that, if given the opportunity, migrants can contribute positively to economic growth and integrate with local communities.
\end{abstract}

Keywords: Refugee Crisis; European Union; Durable Solutions; Responsibility Sharing; Myth of Migration

\section{Introduction}

The emerging displacement of persons in many countries, including Middle Eastern countries, has brought the plight of forced migrants once again to the forefront (World Bank Group, 2017, UNHCR, 2015). In fact, recent United Nations High Commissioner for Refugees (UNHCR) figures show that a record 70.8 million refugees are forcibly displaced. Millions of refugees are in protracted refugee situations (PRSs). The average length of time refugees are trapped in these situations is about 25 years, in comparison with 2003, which was 17 years, and 1991, which was nine years. These figures show that there are more refugees trapped in protracted situations than before and also that their plight takes longer to be resolved. Therefore, from the perspective of persons born in danger zones, one is more likely to be a refugee in 2019 than in 2014, yet less likely to find a durable solution (UNHCR, Global Trend 2019). The growing number of refugees has led to the unprecedented and ongoing political crisis which has arisen from the failure of EU Member States to reach an agreement on the distribution of asylum seekers (Mudde, 2018). Hostility towards migration, especially by the populist and racist political forces across Europe, has had negative effects on European citizens' attitudes to social redistribution in general (Alesina et al., 2018). Today, States focus on restricting the impact of refugees rather than on constructing a form of governance to develop their potential in asylum countries. In fact, in an attempt to reach Europe and find safety, thousands of migrants including women and children, have died in the Mediterranean Sea. European States have adopted strict measures to prevent migrants entering their territory, such as by building fences and militarising their borders. Having found a way to enter, however, migrants are detained and have restricted freedom of movement. Despite all this, only $16 \%$ of refugees are hosted by countries in developed regions (UNHCR, Global Trend 2019).

This research explores the legislation and directives of the European Union (EU), to determine whether these laws are able to address refugees' issues or whether the issue is that Member States are not complying with the refugee regime. Then, the research focuses on certain myths regarding migration to demonstrate that, if given the opportunity, migrants can contribute positively to economic growth and integrate with local communities.

\section{The Applicability of European Union Law to Addressing The Refugee Crisis}

Between 2011-2014, the European Union (EU) amended its legislation on asylum to achieve the overarching objective of establishing a Common European Asylum System (CEAS) (TFEU, 2012). The provisions of the CEAS reinforce those of the Geneva Convention Relating to the Status of Refugees of 1951 (the Refugee Convention), in particular, the principle of non-refoulement, which asserts that a refugee should not be returned to a country where they face a serious threat to their life because of their political opinions. Today, it is generally agreed within the literature that, due to developments in international human rights law in the twentieth century, protection under this right is absolute (Convention against Torture, 1987, Art. 3) The principle of non-refoulement is regarded as a cardinal principle of modern refugee law (ExCom Conclusion No.65 (XLII), 1991, para. (c)) and 
an accepted principle of customary international law (Declaration of States Parties, 2001, preamble para. 4, UNHCR, the Principle of Non-Refoulement, 1994; Goodwin-Gill and McAdam, 2007, pp. 345-354; Lauterpacht and Bethlehem, 2003, pp. 87-177).

The provisions of the CEAS grants international protection to individuals who satisfy the definition of refugee in accordance with Article One of the Refugee Convention. Likewise, the Charter of Fundamental Rights of the EU prohibits the return of refugees to places where they might face persecution, and guarantees the right to asylum (Charter of Fundamental Rights, 2012, Arts 18-19). However, the outbreak of the refugee crisis in 2015, mainly due to the civil war in Syria, resulted in hundreds and thousands of refugees seeking asylum in Europe across the Mediterranean. In response to this, EU Member States implemented restricted borders and laws, and a number of States temporarily reintroduced border controls. This has put the Schengen system of passport-free travel throughout Europe on the brink of collapse (Migration and Home Affairs, 2019). One of the reasons that Member States have adopted such a rigid position, commentators argue, is due to the Dublin Regulation (No. 604/2013). This system places huge pressure on countries of first entry, like Greece and Italy, because they become responsible for handling asylum applications.

The security measures and strict treatment towards refugees has resulted in most being stranded in overcrowded camps in Greece and Italy, and detention centres in Hungary and Macedonia. The treatment of refugees in these countries and the rest of Europe have been contrary to international human rights and international refugee law instruments. The European Court of Human Rights (ECHR) has found these States in violation of the provisions of the European Convention for the Protection of Human Rights and Fundamental Freedoms. For example, in the case of M.S.S. v. Belgium and Greece, the ECHR has prohibited Member States from sending refugees back to Greece under the Dublin Regulation, due to "serious deficiencies" in its asylum system. The Court found that Greece has violated Articles 3 and 6 of the Convention on Human Rights by subjecting refugees to poor living conditions, flawed asylum procedures, and the lack of an effective remedy (Grand Chamber Decision, M.S.S. v. Belgium and Greece, 2011). Alongside this, the UNHCR is concerned that more than 6,000 migrants in Greece live in unheated government shelters, despite freezing conditions (UNHCR, 'Refugees and migrants face high risks in winter weather in Europe').

In Hirsi Jamaa and Others v. Italy, the Court found Italy in violation of Article 3 of the Convention for not allowing migrants to apply for asylum. A number of other countries, including Hungary and Macedonia, have failed to comply with obligations laid down in international and European asylum law (Human Rights Watch, 2016). Many countries have even closed borders on migrants completely, and today thousands of migrants are living in makeshift tents at the Serbian-Hungarian border.

\section{Eu-Turkey Statement: The Failure to Address the Refugee Crisis}

On 18 March 2016, the EU and Turkey reached an agreement to end irregular migration from Turkey to the EU. The purpose of the Statement is to reduce migration flow to the EU through Greece. The agreement outlines that, for every irregular migrant returned to Turkey, another Syrian would be resettled from Turkey to the EU (European Council, 2016). However, the agreement has been subjected to heavy criticism by commentators and humanitarian organisations. For example, Ozturk and Soykan (2019) note that the Statement hinders the accessibility of asylum seekers to protection because they will be returned to Turkey, which is not considered a safe third country within the definition inscribed in EU law. Accordingly, this practice may constitute a breach of international and EU human rights law.The European Foreign Affairs Review has called the agreement "utterly unworkable for logistical, legal, and political reasons". Greene and Kelemen (2016) have called the success of the EU in reducing the flow of refugees into Greece "illusory, and it provides a poor model for the EU's overall approach to migration". This is because the reduction of the inflow of refugees was not due to the agreement but "it was the Balkan countries' decision to close the migration route from the Mediterranean to Germany" (Greene and Kelemen, 2016). It is unlikely that the content of the agreement will be respected by both sides. In fact, on a number of occasions both sides have accused the other of failing to comply with the content of the agreement. On 14th March 2019, a joint Statement by 25 international organisations called for EU Member States to address the plight of 20,000 migrants stranded in unsafe, unhygienic, and inhumane conditions on the Greek islands. They are at high risk of dying from unfavourable weather conditions (Jesuit Refugee Service, 2019). One has to agree with Greene and Kelemen (2016) that "the deal has been a humanitarian and public relations disaster, with human rights groups denouncing it as illegal and an overwhelming majority of Europeans disapproving of the EU's handling of the crisis".

\section{European Member States' Random Reactions to Addressing The Refugee Crisis}

This section shows that individual states have randomly taken action to address the refugee crisis, while collective solutions have stalled, partly due to the lack of a comprehensive and finalized asylum system in Europe. The figures show that some Member States such as Germany, France, Greece, Italy and Spain receive the most asylum applications, with almost $75 \%$ of asylum applications being lodged there. Due to the high rate of acceptance of asylum applicants, for the seventh year in the row, 184,180 applications were made in 2018 alone (EASO, 2019, p. 40).

As noted above, for a number of years the Dublin Regulation, introduced in 2003, has caused friction among Member States. States in the first port of entry into Europe, such as Greece, Italy, and to certain extent Spain, have voiced concerns that they are burdened by the principle that an asylum seeker must ask for asylum only in the 
Member State in which they first arrive. To alleviate the problem, the European Parliament has suggested introducing a quota system to distribute migrants more evenly among Member States. However, this suggestion has never materialized because States could not agree on what these quotas should be like.

In September 2015, the European Commission also adopted a legal instrument on relocation for a two-year period. Relocation was the transfer of an individual in clear need of international protection from one EU Member State to another (European Commission, Fact Sheet, 2015). This measure was adopted by the commission to respond to the immediate refugee crisis and prevent further loss of life at sea. The commission proposed the emergency relocation of 120,000 people from Italy and Greece to another EU Member State (Council Decision (EU) 2015/1601 of 22 September 2015, Art. 4). However, the relocation mechanism only applied to those nationals who have an average EU-wide asylum recognition rate equal to or higher than $75 \%$ (EUROSTAT data). This threshold rate was introduced 'to ensure that all applicants who are in clear and urgent need of protection can enjoy their right of protection as soon as possible; and to prevent applicants who are unlikely to qualify for asylum from being relocated and unduly prolonging their stay in the EU' (European Commission, Fact Sheet, 2015).

The scheme, however, faced many criticisms for its slow implementation. There were bureaucratic and logistical delays with the procedures in Italy and Greece in the early days of the relocation scheme, due to 'the lack of sufficient and timely pledges, insufficient administrative capacity and prohibitive preferences with respect to the profiles of relocation candidates' (ECRE, 2018). Despite the initial difficulties, most countries managed to complete the relocation procedure within the prescribed time limits. The process was also successful because it provided protection to thousands of asylum seekers who were in detention centres in Italy and Greece. If not for the relocation scheme, the asylum seekers might have engaged in irregular onward movement to other countries. Therefore, one can conclude that it 'has thus demonstrated its potential as an instrument of genuine responsibilitysharing within the Common European Asylum System' (ECRE, 2018). However, the scheme expired on 26 September 2017 and so far, European bodies have not proposed a similar programme to address refugee problems in Europe.

Instead, Member States have individually tried to find quick fix solutions to make 'the problem go away' by deterring asylum seekers from entering Europe. For example, in Greece, refugees live in dire situations, and many donot receive basic services such as food and accommodation. This has resulted in Greek authorities pushing refugees towards Macedonia, creating chaos at the border, where refugees are stranded and not allowed to enter the country. In fact, in 2015-2016, there were 1,500 refugees arriving each day. Stephane Moissaing, Medecins Sans Frontieres' head of mission in Serbia,was concerned that 'For months we have called on EU, UNHCR and Serbian authorities to put in place long-term solutions to avoid this catastrophic situation. The collective failure of these institutions has left even the most basic needs uncovered, exposing already vulnerable people to even more suffering'(Thorpe, 2019, p. 247).

In 2015, to address the inflow of refugees to the country, Hungry, contrary to international human rights and refugee law instruments, amended the existing legislation and issued a decree to limit the right of asylum-seekers to seek international protection in Hungary (Hungarian Government Decree 191/2015). This restrictive legal measure was combined with the subsequent practice of building a wall. Hungary also introduced extended detention for any asylum seekers, andthe detention centres are overcrowded and degrading. The UNHCR has criticised the Hungarian government for its lack of appropriate asylum procedure and poor reception conditions, and is concerned by the Hungarians' procedural safeguards, judicial review, and freedom of movement. The UNHCR also notes that these procedures are contrary to European Union and international standards (UNHCR, Hungary: As a Country of Asylum, 2016, p. 4).

Other countries such as Austria, the Netherlands and France have also adopted deterrent measures to discourage asylum seekers from making asylum applications in these countries. Both France and the Netherlands have adopted restrictive measures to make it easier to expel asylum seekers, and persons who do not qualify as refugees will be cut off from food and shelter. Despite these tough measures, the figures show that asylum seekers continue to make asylum applications in their pursuit to find safety. In 2018 alone, almost 124,000 people requested asylum in France, a record number and increase of 23\% from 2017 (Onishi, 2019).Austria's reception centres are overcrowded and deemed inhumane, where hundreds of asylum seekers are forced to sleep outdoors. In fact, one of it centres - designed for a maximum capacity of 1,800 places - was hosting 4,500 persons and more that 1,500 were sleeping outside. Amnesty International (2016) has also criticised the Austrian National Council for rejecting changes in its asylum law, which limits access to protection for thousands of asylum-seekers and breaches its obligations under international law. In 2015, 71 Syrian refugees were found dead in the back of an abandoned lorry on the Austrian highway (Bell and Thorpe, 2016).

Deterrent measures are not the solution, as the figures show that the number of asylum applications in European countries are continuing to rise. The only viable solution, therefore, is not to look at the refugee issue as a temporary phenomenon, but as a permanent one for which long-term measures are required. One such measure is European integration. For example, Germany allows qualified asylum seekers to work to support themselves, and indeedthis is one way to encourage asylum seekers to become independent and make a contribution to society (The VoxEurop, 2016).

\section{Myths of Migration}


In Europe, migration has dominated the media and political debate, and naturally this has impacted on public opinion. Indisputably, misperceptions regarding their impact has led to the polarisation of politics in EU Member States, and to the rise of populist and racist political forces across Europe (Betz 2016; Inglehart, Norris, 2016). There are several myths that the public have about migration and refugees; in this section, only seven are examined. It is important to highlight such myths in order to question the validity and reliability of these most frequently heard misconceptions, to educate the public to separate fact from fear. The analysis shows that most myths are based not on evidence but opinion and inaccuracies. Right-wing political parties argue that refugees are a burden to the economy of the country, butthe figures prove otherwise. This shows the importance of successfully integrating refugees to achieve sustainable development, and counterbalance the negative demographic trends that today exist in Europe.

\subsection{Border Walls Do Not Stop Migration}

Some European Member States have hoped that closing their borders and images of capsized boats and floating bodies will deter migrants from making the irregular move to Europe to make an asylum application. However, existing figures show that the introduction of closed borders does not stop migration into Europe, as migrants seek dangerous terrestrial and maritime routes with the help of smugglers, thus making it more dangerous. The figures also show that thousands of migrants still reach Europe via dangerous routes,paying thousands of dollars to smugglers to avoid border guards, and thereby increasing the market for people-traffickers (The Conversation, 2019).

According to Hein de Haas (2017), another impact of border restrictions is the surge of 'now-or-never' migration, or the pushing of migrants into permanent settlement. For example, $40 \%$ of Surinamese migrated to Holland before visas were introduced. Likewise, in 1991, once Moroccans knew of the introduction of the Schengen Agreement and were 'fearful that they would not be able to re-immigrate after a temporary return home, many opted for permanent settlement'. Today, there are over 700,000 Moroccans in Spain as a result (Hein de Haas, 2017).

\subsection{Has The Refugee Legal Framework Has Not Failed?}

One has to raise the question of whether the international refugee system is broken or have states have failed to share responsibility to address migration issues? The figures show that $90 \%$ of migrants enter Europe legally. This shows that irregular migration is a relatively limited phenomenon. The historical analysis shows that the refugee crisis, such as the 2015 Syrian Civil War and the 1990s Balkan conflicts, are more the exception than the rule and tend not to last (Hein de Haas, 2017). In fact, the European Commission (2019) has noted that 150,000 migrants entered Europe in 2018,the lowest figure for five years.

The figures show that European refugee policies are effective. Khan (2016) rightly notes that 'the international framework which protects asylum seekers' rights in seeking refuge in other States is clearly not a failure. It provides minimum standards of protection'. Therefore, he argues that the amendment or addition of protocols to the existing legal framework might not contribute further in a substantial way, 'because the international legal system, much like domestic legal systems, does not seek to police the individuals who draft it, but instead provides a set of agreements that are meant to be binding. Enforcement lies under the purview of the executive body, not the legislative body' (Khan, 2016, p. 66).

\subsection{Have Migration Policies Become More Restrictive?}

Although recently, as noted above, states have implemented restrictive border controls and visa policies, the analysis shows that contrary to popular belief, migration policies have become less restrictive. In fact, a study was conducted by a number of scholars at the University of Oxford examined 6,500 migration policies adopted by 45 countries, including European countries between 1945-2010. Their analysis showed that 'the laws have become less restrictive, with yearly averages consistently below 0' (Hein de Haas et al, 2018, p. 28).

The recent refugee crisis due to the Syrian war resulted in hundreds of thousands of refugees. European Member States responded by granting asylum and providing resettlement opportunities to those in need of international protection. For example, since 2015, Europe has provided more than 50,000 resettlement places for the most vulnerable individuals. In addition, in 2016 alone, 720,000 refugees were provided protection in Europe and this is three times as many as in Australia, Canada and the United States combined (European Commission, 2019). These figures counter the assumption that Europe has closed its borders and has restrictive policies towards refugees.

\subsection{Do Migrants Burden Or Benefit The Economy?}

As well as being granted international protection, refugees are also entitled to a number of other rights enshrined in the 1951 Refugee Convention, such as freedom of movement, and the right to education and work. These rights have contributed to migrant productivity in the asylum countries. In 2014, a study conducted by the Organisation for Economic Co-operation and Development examined whether migrants affect the labour market, the public purse, and economic growth in asylum countries. The study showed that migrants accounted for $70 \%$ of the increase in the workforce in Europe over the past ten years. Contrary to popular belief, migrants contribute to more in taxes and social contributions than they receive in benefits, and this has a positive impact on economic growth(OECD, 2014). 
Apart from having skills which contribute to human capital development, migrants alsocontribute to technological progress in the destination country. In fact, migrants represent a $14 \%$ increase in the highly educated labour force in Europe. In addition, in countries such as Switzerland and Luxembourg, in a 50-year period, migrants have provided an estimated net benefit of about $2 \%$ GDP to the public purse (OECD, 2014). These figures counter the false assumption that migrants steal local jobs and burden the welfare system. In fact, research shows that most migrants hold jobs for which the local population lacks the skills to do (Hein de Haas, 2017). Furthermore, research conducted by the World Bank and the German Federal Statistical Office found that. over the long term, the number of migrants to Germany strongly correlates with business cycles. The study also found that the increasing numbers of migrants have contributed to boostingthe economy in the country (Hein de Haas, 2017).

Research shows that migration can also address rural areas in Europe that are losing economic, demographic, and decision-making powers due to the outmigration of local residents. For example, Perlik and Membretti explored European migration flows and their impact on the European Alps from the perspective of regional development. Their research, based on three case studies, explores ways in which programs for hosting and integrating migrants can benefit the local residents by contributing in many different ways to the development of mountain areas. Their analysis shows that the integration of refugees as asylum seekers in these regions is a form of social innovation that makes an economic contribution for these remote locations (Perlik and Membretti, 2018, 250).

\subsection{Do We Live In A Time Of Unprecedented Migration?}

Although the number of international migrants has nearly tripled from 93 million in 1960 to 244 million in 2015, the global population has likewise increased from 3 billion to almost 7.3 billion. International migrants are approximately 3\% of the world population (Hein de Haas et al., 2018, p. 8). In 2018, there was 25.9 million refugees in the world. Although this is the highest level ever recorded, they represent a relatively small share of all migrants about $10 \%$. In fact, contrary to popular belief, $86 \%$ of all refugees live in developing countries and nearly four out of every five refugees live in neighbouring countries (UNHCR Global Trends: Forced Displacement in 2018, 2019, p. 2). European countries, by contrast, receive a comparatively low number of refugees, about $0.4 \%$ of the total EU population. In fact, since 1995, refugees have comprised around $0.5 \%$ of the EU population of 508 million, and that is far from unprecedented (Postel, Rathinasamy and Clemens, 2015).

Although today Europe is a popular destination for migrants, attracting between 1.5 and 2.5 million per year due to its strong economy, at the same time between 1-1.5 million people leave the EU every year, creating almost a net balance between outgoing Europeans and incoming migrants. As noted by the United Nations Department of Economic and Social Affairs (2017), migration should be seen 'as an intrinsic part of economic growth and societal change instead of primarily as a problem that must be solved'.

\subsection{Could Migration Resolve The European Ageing Population Problem?}

Europe has an ageing population,which also impacts the working-age population. Although migration can help increase the labour force size, it is not enough to cope with the challenges of population ageing. A report by the European Commission (2018) found that although the EU population will increase from 511 million in 2016 to 520 million in 2070, the working-age population (15-64) will decrease significantly from 333 million in 2016 to 292 million in 2070. This is due to fertility, life expectancy, and migration flow dynamics in Europe. These figures show that a huge gap exists,and that migration alone will not counter Europe's ageing population. The United Nationsstates that to close the gap, the inflow of migration to Europe has to increase to a level that is both 'undesirable and unrealistic'. For example, to address the ageing population in Germany, 3.5 million migrants per year must enter the country, which is 12 times higher than the annual average of 280,000 between 1991-2015. This figure is simply unreachable and undesirable by any society.In Italy, it is predicted that $27 \%$ of the population will be aged over 64 by 2030, compared to just $18 \%$ in 2000. In contrast, the share of population aged (25-44) has decreased from $30.6-26.3 \%$ in the last 15 years, and this in turn threatens the sustainability of the country's pension system (Birot, 2018). Migration could help increase fertility rates, although this is expected to drop by seven million over the next 50 years. According to Hein de Haas (2017), the question for the future may therefore be not how to prevent migrants from coming, but how to attract them to address this ever-growing phenomenon.

\subsection{Would Increasing Resettlement Opportunities Address Irregular Migration?}

Every year, tens of thousands of people risk their lives trying to enter the EU in an irregular way and many die in the attempt, as demonstrated by recent events, notably in the Mediterranean (McIntyre et al., 2018). This study argues that, due to the lack of resettlement opportunities and the inefficient delivery of these as a solution, thousands of refugees every year take irregular or dangerous routes to find safety. Indeed, the efficient implementation of this solution would benefit those countries which provide them. However, this is not to say that increasing resettlement opportunities would stop other immigration attempts. Likewise, Troeller (2002, p. 92) notes that " $\mathrm{t}]$ here is no necessary or proven correlation between increased resettlement and a reduction in the number of those legitimately or illegitimately seeking asylum'; he admits, however, that 'increased resettlement opportunities may reduce the motivation to move "irregularly" in the search for asylum'. The spokesperson for the UN High Commissioner for Refugees, William Spindler, appealed to the EU to ensure the provision of the maximum number of ways to offer legal entry to refugees. He has condemned as shameful the fact that only 2,000 
migrants have been resettled, despite a relocation plan for 160,000 people, stating that '[The EU's Sophia military mission] is meant to stop traffickers from bringing over migrants from Africa. But the consequences have been opposite to the desired effect. Human traffickers have begun using inflatable vessels and the risks of shipwreck have increased' (UNHCR, 2015).

According to Djajić (2014, pp.83-84), asylum seekers have two main ways of reaching industrialised countries: irregular migration, which comes at a high cost and risk, with the aid of human smugglers and often without appropriate documentation, or through the UNHCR's resettlement submission programmes, which are available for only a small proportion of refugees. The UNHCR argues that ' $\mathrm{r}$ ] esettlement can have a positive, mitigating influence on irregular movements when it is implemented on the basis of clear and consistent criteria, and when it is used as a policy tool to reinforce protection in countries of first asylum' (UNHCR, 1997, p.671).

Loescher and Milner (2005, p.7) go further by stating that Protracted Refugee Situations are a principal source of many of the irregular movements of people around the world. In fact, a number of European States have taken measures, such as increasing resettlement opportunities to address and manage irregular migration (Selm, 2004, p.39; European Migration Network, 2012, pp.3-135). However, as noted by Troeller (2002, p. 92), there is no empirical evidence that increasing resettlement opportunities will halt irregular migration. The political turmoil in the country and the lack of adequate protection in neighbouring countries, alongside the lack of resettlement opportunities to third countries, is the contributing factor for many refugees who have been left with no choice but to commit to the dangerous route of irregular migration to European countries with the assistance of smugglers (Sperl, 2007, pp.1-19). Refugees have chosen this route to escape the risk of being arrested, detained or forcibly returned. In fact, irregular migration has become the only option for refugees to find safety, since there are no other legal ways to find protection.

Alonso (2010, p.321) notes that limited places for resettlement have made irregular migration an attractive alternative for refugees to seek much needed protection in industrialised countries. Equally, the former UNHCR High Commissioner, Ruud Lubbers, noted that if European countries become better at applying durable solutions, and supporting those States which host large numbers of refugees, then there will be fewer refugees who seek dangerous solutions in the form of human trafficking and smuggling. However, he warned that not finding a durable solution would result in refugees being forced to go on the move irregularly, using criminal networks (UNHCR, High Commissioner Statement, 2001).

The EU Agency for Fundamental Rights (FRA) has called on the EU and its Member States to offer more possibilities for persons in need of international protection to arrive in the EU legally, and in safety. The FRA notes that this can be done through the implementation of resettlement programmes to explore distinct humanitarian admission schemes, not limited to those who qualify as refugees. By putting in place such programmes, EU Member States not only enable more persons in need of international protection to enter the EU, but also contribute to reducing their need to resort to smuggling networks to reach safety (European Union Agency for Fundamental Rights, 2015). Indeed, this is a viable alternative solution to risky irregular entry.

The figures show that opportunities to enter the EU lawfully, through resettlement, are extremely limited for persons in need of international protection. In 2018, the UNHCR estimated that 1.4 million refugees needed resettlement, butonly 81,300 places were provided. The gap between needs and actual resettlement places exceeded 90\%, and continues to grow (UNHCR Global Trends, 2019, p.31). Only 29 countries in the world provide these places and almost half of the Member States do not even have a regular resettlement programme in place (ICMC, 2013). However, the UNHCR warns that increasing resettlement opportunities alone will not combat irregular migration (UNHCR, 2002, paras. 10 and 11(c); for further analysis in the literature, see Selm, 2013, pp.1-71).

\section{Conclusion}

In the past few years, the refugee crisis in the international arena has once again become the subject of media attention and political discussion, with multiple consequences. Hundreds of people have drowned in the Mediterranean, families have been living in unfit shelters in Greece, Italy, Macedonia and Hungry, asylum seekers have risked their life in unsafe boats, freezer lorries, and packed vans, as they try to reach safe haven in Europe. Being a refugee is not crime, and European Member States must offer safe passage for asylum seekers to enter Europe. At present, EU Member States have failed to take adequate action to prevent loss of life.

Against this background, misperceptions regarding the impact of international migration have led to the polarisation of politics in EU Member States, and to the rise of populist and racist political forces across Europe. However, contrary to media bias and right-wing politicians, refugees do not claim asylum to receive social security, but to improve their lives and find safety. In fact, most refugees wish to integrate into society and contribute to the economy of the asylum country. Contrary to popular belief, most would like to return to their region of origin, but the lack of change in circumstance in these regions means that many have no intention to voluntarily repatriate. Similarly, today, less than one percent of refugees are resettled, and so unless resettlement opportunities increase significantly, more than half of the refugees who need resettlement will be confined in camps or remain in a state of limbo in asylum countries without any solution in sight. Therefore, the lack of availability of three durable solutions for refugees - voluntary repatriation, local integration, and resettlement to a third country -has contributed to their never-ending predicament. 
In this research, the most important issues facing refugees in Europe were examined. In order to do this, we discussed the relevance of EU laws in regard to the protection provided to refugees entering Europe. The international community has an obligation to protect refugees and provide the rights outlined in the provisions of international human rights and international refugee law instruments. The research also identified the difficulties that refugees face entering Europe and claiming asylum, such as discrimination, deportation, and, contrary to international law, arrest and detainment. The research critically reviewed the existing mechanisms available to provide international protection. In this regard, the Dublin Regulation has faced many challenges due to the unfair distribution of refugees across Member States. Countries such as Greece and Italy have faced a great burden with huge applicationsfor asylum, while others such as Hungary have focused on reinforcing national borders. Many asylum seekers have died due to freezing weather conditions and thousands more remain at risk while sleeping on the streets or in tents and inadequate shelters.

The research has also highlighted some of the misconceptions which exist among Europeans and media outlets. Contrary to popular belief, stricter borders will not stop migration. Instead, traffickers and smugglers will benefit by finding a way to bypass the border control.The existing refugee legal framework, whenimplemented appropriatelyby States, has not failed. Indeed, European policies to provide international protection have not become restrictive, contrary to popular belief,as the figures show they have become even more liberal in comparison to 50 years ago. Moreover, data show that refugees benefit the local community and contribute economically and socially to European society. Refugees are not a burden but a potential resource for the destination country. The review of the historical background showed that we do not live in a time of unprecedented migration. Although migration has increased, the population in the world has also increased. The demographic review shows that Europe's population is getting older and migration as it stands would not be able to address the significant decrease in the working-age population.

A review of UNHCR figures showed that only a small percentage of refugees are offered resettlement. To find safety, tens of thousands of people currently risk their lives trying to enter the EU in an irregular way and many die in the attempt.Although it was discussed that increasing resettlement opportunities may reduce the motivation for refugees to make a dangerous move in search of asylum, this is not to say that increasing resettlement opportunities would stop refugees taking irregular or dangerous routes to find safety.

\section{Recommendations}

After a thorough analysis and in-depth evaluation of the refugee situation in the world, and in Europe in particular, this research makes certain recommendations and suggestions:

i. It is the duty of the international community and States, both collectively and individually, to provide protection to refugees in accordance with their international obligations;

ii. It is time for the EU to work as a Union, as the name suggests, to respond to the refugee crisis, and work with international humanitarian organisations to provide protection and find durable solutions;

iii. States have to open their borders, accept asylum seekers, and determine cases individually, to make a status decision on this basis. Deportation, discrimination, and detention must be avoided. Such practices are in violation of international law;

iv. Without urgent EU action, the refugees' situation will not improve in the near future, and instead will generate further challenges;

v. States that do not yet have resettlement programmes need to show international solidarity by providing resettlement opportunities. It is also strongly recommended thatthe States which already have a resettlement programme should increase their quota and accommodate the growing need for resettlement places. By offering resettlement places, European Member States show solidarity withasylum countries and ease the burden on the States that host significantly large numbers of refugees.

vi. Europe must provide safe and legal pathways for those in need of international protection. Otherwise, smugglers and traffickers will continue raking in profits to the tune of billions of euros;

vii. The European Commission must work with Member States to establish a sustainable and well-functioning asylum system. Member States should appropriately implement the Dublin Regulation,which enforces a fair distribution of refugees around Europe, and Member States should reach an agreement on the distribution of asylum seekers on an equal basis for all States to share responsibility;

viii. In the meantime, European Member States must allow rescue operations to continue in the Mediterranean to save lives.

\section{References}

1. Case Law

2. Hirsi Jamaa and Others v. Italy, App. No. 27765/09 (ECHR Feb. 23, 2012)

3. M.S.S. v. Belgium and Greece, App. No. 30696/09 (ECHR Jan. 21, 2011)

4. Journals:

5. Azfer Ali Khan, 'Can International Law Manage Refugee Crises?' (2016) 5 Oxford University Undergraduate Law Journal 54-66. 
6. Gary Troeller, 'UNHCR Resettlement: Evolution and Future Direction' (2002) 14(1) International Journal of Refugee Law 85.

7. Gil Loescher and James Milner, 'Protracted Refugee Situations: Domestic and International Security Implications' (2005) 375(45) Adelphi Papers 7.

8. Joanne Van Selm, 'The Strategic Use of Resettlement: Changing the Face of Protection?' (2004) 22(1) Refuge 39.

9. Manfred Perlik and Andrea Membretti, 'Migration by Necessity and by Force to Mountain Areas:An Opportunity for Social Innovation’ (2018) 38(3) Mountain Research and Development Journal 250-264.

10. Slobodan Djajić, ‘Asylum Seeking and Irregular Migration' (2014) 39 International Review of Law and Economics 83-84.

11. UNHCR, 'Resettlement: An Instrument of Protection and a Durable Solution' (1997) 9(4) International Journal of Refugee Law 666.

12. Book

13. Beatriz Tomé Alonso, 'Iraqi Conflict-induced Refugees and Their Regional Impact', in Antonio Marquina Barrio (ed), Migration Flows, Economic Crisis, Environmentally-induced Migration and Human Security: Visions from Asia and Europe (UCM 2010).

14. Erika Feller, Volker Türk and Frances Nicholson, Refugee Protection in International Law: UNHCR's Global Consultations on International Protection (Cambridge University Press, 2003)

15. Guy Goodwin-Gill and Jane McAdam, The Refugee in International Law (Oxford University Press, 3rd Edition, 2007).

16. Nick Thorpe, The Road Before Me Weeps: On the Refugee Route Through Europe (Yale University Press, 2019).

17. UNHCR Documents

18. UNHCR, 'Another Weekend of Tragedy Marks the Mediterranean, with up to 40 Refugees Dead' (News

19. Stories, 20 September 2015). Available at: <http://www.unhcr.org/55ff19226.html> accessed 13 October 2015.

20. UNHCR, 'Progress Report on Resettlement' (ExCom Standing Committee 54th meeting, 5 June 2012) UN Doc. EC/63/SC/CRP.12, para. 3.

21. UNHCR, 'Refugees and migrants face high risks in winter weather in Europe' available at: http://www.unhcr.rs/en/dokumenti/saopstenja-za-medije/izbeglice-i-migranti-suoceni-sa-visokimrizicima-po-zimi-u-evropi.html

22. UNHCR, 'Statement by Mr. Ruud Lubbers, United Nations High Commissioner for Refugees, to the European Conference on Migration, Brussels (HC Statements, 16 October 2001). Available at: <http://www.unhcr.org/3bdd46c17.html> accessed 17 October 2015.

23. UNHCR, 'Strengthening and Expanding Resettlement Today: Dilemmas, Challenges and Opportunities' (Global Consultations on International Protection 4th Meeting, EC/GC/02/7 25 April 2002). Available at: <http://www.refworld.org/pdfid/3d62679e4.pdf> accessed 5 February 2015.

24. UNHCR, 'Time running out to Resolve Refugee Emergency in Europe' (News Stories, 18 September 2015). Available at: <http://www.unhcr.org/55fc0e386.html> accessed 13 October 2015.

25. UNHCR, 'UNHCR Global Trends: Forced Displacement in 2018' (20 June 2019). Available at: <https://www.unhcr.org/5d08d7ee7.pdf> accessed 25 July 2019.

26. UNHCR, 'UNHCR Projected Global Resettlement Needs 2020' (1-2 July 2019) 9. Available at: <https://www.unhcr.org/5d1384047.pdf> accessed 25 July 2019.

27. UNHCR, 'UNHCR Urges Governments to Continue High Seas Live-Saving Operations' (News Stories, 12 May 2015). Available at: 〈http://www.unhcr.org/5551f31cfdd.html〉 accessed 13 October 2015.

28. UNHCR, Hungary: As a Country of Asylum (May 2016). Available at: https://www.refworld.org/pdfid/57319d514.pdf

29. UNHCR, the Principle of Non-Refoulement as a Norm of Customary International Law. Response to the Questions Posed to UNHCR by the Federal Constitutional Court of the Federal Republic of Germany in Cases 2 BvR 1938/93, 2 BvR 1953/93, 2 BvR 1954/93 (31 January 1994) available at: <http://www.refworld.org/docid/437b6db64.html> accessed 20 October 2015.

30. Legislation

31. Charter of Fundamental Rights of the European Union, 2012 O.J. (C 326) 391.

32. Consolidated Version of the Treaty on the Functioning of the European Union (TFEU), 2012 O.J. (C 326) 47

33. Declaration of States Parties to the 1951 Convention and or Its 1967 Protocol relating to the Status of Refugees(Ministerial Meeting of States Parties, 12-13 December 2001) UN Doc. HCR/MMSP/2001/09.

34. Dublin RegulationNo. 604/2013 of the European Parliament and of the Council of 26 June 2013, Official Journal of the European Union L 180/31

35. Government Decree 191/2015 of 21 July 2015 on the National Designation of Safe Countries of Origin and Safe Third Countries, which entered into force on 22 July 2015, available in unofficial English translation at http://www.refworld.org/docid/55ca02c74.html

36. Reports 
37. Amnesty International, Austria: Parliament must overturn proposal to deny refugee protection to thousands (27 April 2016). Available at: https://www.amnesty.org/en/latest/news/2016/04/austriaasylum-law-refugees/

38. Bethany Bell and Nick Thorpe, 'Austria's Migrant Disaster: Why did 71 die?'(25 August 2016). Available at: https://www.bbc.com/news/world-europe-37163217

39. European Commission, 'Refugee Crisis - Q\&A on Emergency Relocation' (European Commission - Fact Sheet, Brussels, 22 September 2015) Available at: http://europa.eu/rapid/press-release_MEMO-155698_en.htm\#_ftnref1

40. European Commission, 'the 2018 Ageing Report: Economic \& Budgetary Projections for the 28 EU Member States (2016-2070)’ (Institutional Paper 079, MAY 2018).

41. European Commission, Council Decision (EU) 2015/1601 of 22 September 2015, Establishing Provisional Measures in the area of International Protection for the Benefit of Italy and Greece, 24 September 2015, L 248/80.

42. European Council on Refugees and Exiles (ECRE), Relocation of Asylum Seekers in Europe: A View from Receiving Countries' (Asylum Information Database (aida), May 2018). Available at: http://www.asylumineurope.org/sites/default/files/aida_brief_relocation.pdf

43. European Council, EU-Turkey statement (18 March 2016). Available at: https://www.consilium.europa.eu/en/press/press-releases/2016/03/18/eu-turkey-statement/

44. Hannah Postel, Cynthia Rathinasamy and Michael Clemens, 'Europe's Refugee Crisis Is Not as Big as You've Heard, and Not Without Recent Precedent' (Center for Global Development, 10 September 2015). Avaliable at: https://www.cgdev.org/blog/europes-refugee-crisis-not-big-youve-heard-and-not-withoutrecent-precedent

45. Hein de Haas et al, 'International Migration Trends, Determinants and Policy Effects' (International Migration Institute Network (IMIn) Working Paper Series no. 142, January 2018).

46. Hein de Haas, Myths of Migration: Much of what we think we know is wrong (29 March 2017).Available at: http://heindehaas.blogspot.com/2017/03/myths-of-migration-much-of-what-we.html

47. Human Rights Watch, Greece/Macedonia: Asylum Seekers Trapped at Border (11 February 2016). Available at: https://www.hrw.org/news/2016/02/11/greece/macedonia-asylum-seekers-trapped-border

48. Jesuit Refugee Service, 'Third anniversary EU-Turkey Statement' (14 March 2019). Available at:http://www.jrseurope.org/news_detail?TN=NEWS-20190313033929\&L=EN

49. Joanne van Selm, 'Great Expectations: A Review of the Strategic Use of Resettlement' (UNHCR Evaluation Reports, PDES/2013/13, August 2013) 1-71. Available at: file:///E:/Research/The\%20Role\%20of\%20UNHCR\%20in\%20Finding\%20Durable\%20Solutions\%20fo r\%20the\%20Refugees/resettlement/520a3e559.pdf

50. Markus Sperl, 'Fortress Europe and the Iraqi “intruders": Iraqi asylum-seekers and the EU, 2003-2007' (2007) New Issues in Refugee Research, Research Paper No. 144, 1-19.

51. Megan Birot, what does a plummeting birth rate mean for Italy's future? (The Locals, 27 June 2018). Available at:https://www.thelocal.it/20180627/italy-declining-birthrate-population

52. Megan Greene and R. Daniel Kelemen, Europe's Failed Refugee Policy: The Crisis in the Mediterranean Continues (Foreign Affairs, 28 June 2016). Available at: https://www.foreignaffairs.com/articles/europe/2016-06-28/europes-failed-refugee-policy

53. Migration and Home Affairs,Temporary Reintroduction of Border Control (2019). Available at: https://ec.europa.eu/home-affairs/what-we-do/policies/borders-and-visas/schengen/reintroductionborder-control_en

54. Neva Övünç Öztürk and Cavidan Soykan, Third Anniversary of EU-Turkey Statement: A Legal Analysis (3 October 2019). Available at:https://tr.boell.org/en/2019/10/03/third-anniversary-eu-turkey-statementlegal-analysis

55. Niamh McIntyre and others, 'It's 34,361 and rising: how the List tallies Europe's migrant bodycount' (20 June 2018). Available at: https://www.theguardian.com/world/2018/jun/20/the-list-europe-migrantbodycount

56. Norimitsu Onishi, France Announces Tough New Measures on Immigration (6 November 2019). Available at: https://www.nytimes.com/2019/11/06/world/europe/france-macron-immigration.html

57. The Conversation, 'Europe's refugee crisis explains why border walls don't stop migration' (30January 2019). Available at:https://theconversation.com/europes-refugee-crisis-explains-why-border-walls-dontstop-migration-110414

58. The European Asylum Support Office (EASO) Annual Report on the Situation of Asylum in the European Union 2018 (June 2019). Available at: https://www.easo.europa.eu/sites/default/files/easo-annual-report2018-web.pdf

59. The European Migration Network, 'Practical Measures to Reduce Irregular Migration' (October 2012) 3135. Available at: <http://www.emn.lv/wpcontent/uploads/EMN_Synthesis_Report_Irregular_Migration_April_2013.pdf> accessed 12 October 2015. 
60. The European Union Agency for Fundamental Rights (FRA), 'Legal Entry Channels to the EU for Persons in Need of International Protection: a Toolbox' (FRA Focus 02/2015). Available at: http://fra.europa.eu/sites/default/files/fra-focus_02-2015_legal-entry-to-the-eu.pdf

61. The Organisation for Economic Co-operation and Development, 'Migration Policy Debates' (OECD, May 2014).

Available

at: https://www.oecd.org/migration/OECD\%20Migration\%20Policy\%20Debates\%20Numero\%202.pdf

62. The VoxEurop, 'Refugee Crisis: An Unprecedented Failure by the EU and its Member States' (4 June 2016). Available at: https://voxeurop.eu/en/content/press-review/5090942-unprecedented-failure-euand-its-member-states

63. Theresa Papademetriou, Refugee Law and Policy: European Union (Library of Congress, March 2016). Available at: https://www.loc.gov/law/help/refugee-law/europeanunion.php\#_ftn12

64. United Nations Department of Economic and Social Affairs, Population Facts: Migration and Population Change - Drivers and Impacts No. 2017/8 (December 2017).

65. World Bank Group, Forcibly Displaced: Towards a Development Approach Supporting Refugees, the Internally Displaced, and Their Hosts (2017). Available at: https://www.unhcr.org/5975a93e7.pdf 